\title{
A Convenient Preparation of Halide-Containing Quinolinic and Cinchomeronic Acid
}

\author{
Kwang-Nym Cho, Min-Sup Park, Young-Key Shim, and Kee-In Lee* \\ Bio-Organic Science Division, Korea Research Institute of Chemical Technology, \\ P.O. Box 107, Yusong, Daejon 305-600, Korea \\ Received June 24, 2002
}

Key Words : Ruthenium tetroxide. Quinoline. Isoquinoline. Py ridinedicarboxylic acid

The chloropyridine moiety is a ker structural element of many biologically active compounds such as (-)-epibatidine. ABT-594, and imidacloprid. acting at mammalian and insect nicotinic acetylcholine receptor $(\mathrm{nAChR}){ }^{l}$ And also. it has been involved as building blocks in a variety of transformation including cross-coupling amination. and metalation reactions. ${ }^{2}$

In our recent efforts toward the synthesis of $n \mathrm{AChR}$ antagonists. it is envisioned that a convenient synthesis of pyridinedicarboxylic acids would offer the most concise synthetic route to the pyrrolopyridine molecules. ${ }^{3}$ This chemistry highly depends on the availability of quinolinic and cinchomeronic acid precursors. Although there are many methods for the preparation of halide-containing pyridinedicarboxylic acids. a facile and reliable preparation of such compounds is poorly documented ${ }^{4}$ The described methods mainly included ozone ${ }^{\text {ta }}$ and electrolytic oxidation ${ }^{\text {th }}$ of quinoline and isoquinoline, and potassium permanganate oxidation $^{\text {to }}$ of merimine. However. these methods suffered from many aspects of scope and limitation: a low yield a loss of halogen. and a restricted application. In the ozone approach. 4-chloroisoquinoline was oxidized to give 5chlorocinchomeronic acid in poor yield. The procedure for the oxidation of merimines to the corresponding cinchomeronic acids required multi-preparative steps. The electrolytic oxidations of 2- and 4-chloroquinoline were unsuccessful. due to the dehalogenation and polymerization. It is noteworthy that the directed lithiation of 2- and 6-chloronicotinic acid furnished 2- and 6-chlorocinchomeronic acid in 69 and $74 \%$ yield. respectively. ${ }^{2 b}$

In continuing the search for better oxidative methods. we turned our attention to the ruthenium tetroxide oxidation of benzene-containing heterocyclic compounds. Notably, one method of particular interest for its simplicity and convenience is the ruthenium tetroxide oxidation on aromatic compounds. It is well known that the oxidation of aromatic rings to carboxylic acids with ruthenium tetroxide is a very efficient and simple reaction using sodium periodate periodic acid. or sodium hypochlorite as the oxidant. However. the application of ruthenium tetroxide oxidation to halidecontaining heterocyclic derivatives has been but scantly investigated. Only a few examples were reported in the oxidation of quinoline and isoquinoline, in which isoquinoline mainly gave phthalic acid. ${ }^{5 b}$ Here. we would like to report a general procedure for the convenient preparation of halide-containing quinolinic and cinchomeronic acids. employing ruthenium tetroxide oxidation of the corresponding quinolines and isoquinolines. ${ }^{\text {if }}$

First. we examined the ruthenium-catalyzed oxidation of 2-chloroquinoline 1a using ruthenium tetroxide. generated in sint from $\mathrm{RuCl}_{3}$ and $\mathrm{H}_{3} \mathrm{IO}_{6}$. in a biphasic solvent system $\left(\mathrm{CCl}_{4} . \mathrm{CH}_{2} \mathrm{CN}, \mathrm{H}_{2} \mathrm{O}\right){ }^{5 e}$ We slightly modified the process. converting 1a to the corresponding pyridinedicarboxylic acid. Without further purification. the acid was directly subjected to esterification with MeI and $\mathrm{Cs}_{2} \mathrm{CO}_{3}$ in DMF to give the ester $\mathbf{1 b}$ in $75 \%$ yield. It turned out the chloropyridine ring in quinoline is much more resistant to the oxidation than the benzene. With this promising result. we extended the oxidation to the readily available quinolines and isoquinolines. The starting materials. 2-bromoquinoline (2a). 2-chloro-4-methỵlquinoline (3a), and 2-bromo-4metlylquinoline (ta). were obtained by the halogenation of the corresponding hydroxyquinolines using $\mathrm{PPh}_{3}$ and $N$ halosuccinimide as previously described. ${ }^{6}$ The others were commercially available. The results are summarized in Table 1. It seems the chloride (1a) is much more tolerable to this oxidative process than the bromides ( $2 \mathbf{a}$ and $\mathbf{5 a}$ ). A survey of data showed the yields of diacids were strongly dependent on the positions of halogen atoms. The 4-substituted quinolines ( $3 a$. $4 a$ and $6 a$ ) did not give any better results. It is noteworthy that no product was observed in the 2- (1a) and 4-chloroquinoline (6a) by the electrolytic oxidation. ${ }^{\text {th }}$ The interesting feature was observed that the oxidation of 2halo-4-methylquinolines ( $3 \mathbf{a}$ and $+\mathbf{a}$ ) allowed a lower yield than that of 2-haloquinolines (1a and 2a). This result strongly suggested that the 4-methylquinoline. activated by electron-releasing substituent is much labile to the oxidation rather than unsubstituted quinoline. This observation is in agreement with the results reported by others. ${ }^{\text {ta. }} .5 \mathrm{~b} . \mathrm{d}-\mathrm{e}$ The results demonstrated that aromatic derivatives bearing electron-donating groups revealed the easy of oxidation of an aromatic rings. Contrastingly, the electron-withdrawing groups. such as nitro group and halogens markedly reduced their reactivity. The oxidation of haloisoquinolines, $7 \mathbf{a}$ and 8a. gave cinchomeronic acids. $7 \mathbf{b}$ and 8 b. in 24 and $26 \%$ yield. respectively. The halide effect on the rutheniumcatalyzed oxidation of haloisoquinolines is well illustrated by the contrasting result of isoquinoline. which mainly gave phthalic acid in $58 \%$ yield ${ }^{5 \mathrm{t}}$ In these cases of $7 \mathbf{a}$ and $8 \mathbf{a}$. the destruction of benzene ring was predominant. As mentioned 
Table 1. Preparation of halide-containing pyridinedicarbosylic acids

Entry

above. 4-chloroisoquinoline was oxidized using ozone in $95 \%$ acetic acid solution to give 5 -chlorocinchomeronic acid in only $8 \%$ yield. ${ }^{\text {Ac }}$

In summary halide-containing quinolines and isoquinolines were subjected to nuthenium-catalyzed oxidation to give pyridinedicarboxylic acids in fair yield. It has proven that this procedure is efficient for the oxidation of both halide-containing quinoline and isoquinoline and superior to the previously described methods. Currently. we are investigating on some halide-containing quinolinic and cinchomeronic acids as new scaffolds for designing $\mathrm{nACh} R$ ligands.

\section{Experimental Section}

6-Chloropyridine-2,3-dicarboxylic Acid Dimethyl Ester (1b). A round-bottomed flask was charged with acetonitrile $(60 \mathrm{~mL})$, carbon tetrachloride $(60 \mathrm{~mL})$, water $(90 \mathrm{~mL})$. periodic acid (99.0 g. $434 \mathrm{mmol}$ ), and ruthenium (III) trichloride hydrate (152.8 $\mathrm{mg} .0 .74 \mathrm{mmol}$ ). The flask contents were vigorously stirred until both phases became clear. To the flask added 2-chloroquinoline 1 a $(5.0 \mathrm{~g} .30 .56$ mmol) in portions. and the reaction mixture was stirred for 4 h. keeping the temperature within the range of $25-40^{\circ} \mathrm{C}$ by the control of the stirring speed with an ice-water bath. until no starting material was detected by TLC. The reaction mixture was cooled to $0^{\circ} \mathrm{C}$, and ether was added with vigorous stirring for $10 \mathrm{~min}$. The organic layer was separated and the aqueous layer was extracted with ether. The combined organic layers were washed with brine. dried over magnesium sulfate, and evaporated to yield a crude oil containing periodic acid. Without any purification, the crude oil was redissoved in $N . N^{\prime}$-dimethylfomamide $(100 \mathrm{~mL})$. To this solution was added methyl iodide (24.2 g. 170.6 mmol) and cesium carbonate $(27.79 \mathrm{~g}, 85.3 \mathrm{nmol}$ ) and the mixture was stirred at room temperature for overnight and diluted with ethyl acetate. The combined organic layers were washed successively with water. dried over magnesium sulfate and evaporated under reduced pressure to give an oily residue. The residue was purified by flash cluromatography on silica gel with ethyl acetate/hexane $(1: 7)$ as the eluent to give $5.26 \mathrm{~g}(75 \%)$ of $1 \mathrm{~b}$ as a solid: $\mathrm{mp} 46-47{ }^{\circ} \mathrm{C} ;{ }^{\mathrm{l}} \mathrm{H}$ NMR $\left(\mathrm{CDCl}_{3}\right) \delta 8.14$ (d. $\left.J=8.1 \mathrm{~Hz} . \mathrm{HH}\right) .7 .49(\mathrm{~d} . J=8.1 \mathrm{~Hz} . \mathrm{lH})$, 3.96 (s. 3H), 3.93 (s. $3 \mathrm{H}):{ }^{13} \mathrm{C} \mathrm{NMR}\left(\mathrm{CDCl}_{3}\right) \delta \mathrm{l} 65.1,164.2$, $153.8,151.3 .140 .1,125.5 .124 .0,52.9,52.8$; EIMS $m z$ (rel intensity) $231\left(\mathrm{M}^{+}, 1\right) .229\left(\mathrm{M}^{-}, 4\right), 198$ (34). 140 (35). 102 (100), 76 (88); Anal. Calcd for $\mathrm{C}_{9} \mathrm{H}_{8} \mathrm{ClNO}_{4}$ : C. 47.08; $\mathrm{H}$, 3.51; N. 6.10. Found: C. 47.12; H. 3.49: N, 6.02.

6-Bromopyridine-2,3-dicarboxylic Acid Dimethyl Ester (2b). ${ }^{1} \mathrm{H} \mathrm{NMR}\left(\mathrm{CDCl}_{3}\right) \delta 8.06(\mathrm{~d} . J=8.3 \mathrm{~Hz}, \mathrm{lH}) .7 .68(\mathrm{~d} . J$ $=8.3 \mathrm{~Hz} . \mathrm{lH}$ ), 3.99 (s. $3 \mathrm{H}$ ). 3.93 (s. 3H); EIMS $m z$ (rel intensity) $275\left(\mathrm{M}^{-}, 0.5\right) .273\left(\mathrm{M}^{+} .0 .6\right) .214(43) .184$ (100). $88(15)$.

6-Chloro-4-methylpyridine-2,3-clicarboxylic Acid Dimethyl Ester (3b). ${ }^{1} \mathrm{H}$ NMR $\left(\mathrm{CDCl}_{3}\right) \delta 7.40$ (s. IH). 3.98 (s. $3 \mathrm{H}$ ). 3.96 (s. $3 \mathrm{H}$ ). $2.4 \mathrm{l}$ (s. $3 \mathrm{H}$ ); EIMS $m z$ (rel intensity) 245 (M- 5). 243 (M- . 16). 212 (95). 127 (100). $116(34)$.

6-Bromo-4-methylpyridine-2,3-dicarboxylic Acid Dimethyl Ester (4b). ${ }^{1} \mathrm{H}$ NMR (CDCl$\left.)_{3}\right): \delta 7.56$ (s. lH), 3.97 $(\mathrm{s}, 3 \mathrm{H}), 3.96(\mathrm{~s}, 3 \mathrm{H}), 2.39(\mathrm{~s}, 3 \mathrm{H})$ : EIMS $m z$ (rel intensity) $289\left(\mathrm{M}^{+}\right.$. 14). $287\left(\mathrm{M}^{-}, 13\right), 258(57), 199(97), 171(100)$.

5-Bromopyridine-2,3-dicarboxylic Acid Dimethyl Ester (5b). mp 72-73 ${ }^{\circ} \mathrm{C}:{ }^{l} \mathrm{H}$ NMR $\left(\mathrm{CDCl}_{3}\right) \delta 8.81$ (d. $J=2.2 \mathrm{~Hz}$ 1H). 8.29 (d. $J=2.2 \mathrm{~Hz} .1 \mathrm{H}$ ). 3.99 (s. $3 \mathrm{H}$ ). 3.95 (s. 3H): EIMS $m z$ (rel intensity) $275\left(\mathrm{M}^{-}, 2\right) .273\left(\mathrm{M}^{-}, 9\right) .244$ (100). $242(91)$.

4-Chloropyridine-2,3-dicarboxylic Acid Dimethyl Ester (6b). mp $106^{\circ} \mathrm{C}:{ }^{l} \mathrm{H}$ NMR $\left(\mathrm{CDCl}_{2}\right) \delta 8.77$ (d. $J=5.3 \mathrm{~Hz}$. lH). 7.52 (d. $J=5.3 \mathrm{~Hz}, 1 \mathrm{H}$ ), 4.02 (s. $3 \mathrm{H}) .3 .75$ (s. $3 \mathrm{H}$ ): EIMS $m z$ (rel intensity) $231\left(\mathrm{M}^{-}, 1\right), 229\left(\mathrm{M}^{+}, 3\right), 198(45)$. $169(70), 113(100), 76(73)$.

2-Chloropyridine-3,4-dicarboxylic Acid Dimethyl Ester (7h). $\operatorname{mp} 57-58^{\circ} \mathrm{C}:{ }^{1} \mathrm{H} \mathrm{NMR}\left(\mathrm{CDCl}_{3}\right) \delta 8.59$ (d. $J=5.1 \mathrm{~Hz}$. 1H). $7.79(\mathrm{~d} J=5.1 \mathrm{~Hz}, 1 \mathrm{H}), 4.01$ (s. $3 \mathrm{H}) .3 .95$ (s. 3H): EIMS $m z$ (rel intensity) $231\left(\mathrm{M}^{-}, 6\right) .229\left(\mathrm{M}^{-}, 10\right), 200(42)$. 198 (100). 163 (23).

5-Bromopyridine-3,4-dicarboxylic Acid Dimethyl Ester (8b). mp 65-66 ${ }^{\circ} \mathrm{C}:{ }^{l} \mathrm{H}$ NMR $\left(\mathrm{CDCl}_{3}\right) \delta 9.08$ (s. 1H). 8.87 (s. 1H). 3.96 (s. $3 \mathrm{H}$ ). 3.90 (s. $3 \mathrm{H}$ ): EIMS $m z$ (rel intensity) 275 $\left(\mathrm{M}^{-}, 22\right) 273\left(\mathrm{M}^{+}, 20\right) .244(100), 242(91)$. 
Acknow ledgment. We would like to thank the Ministry of Science \& Technology of Korea (KO-9903-03) for financial support.

\section{References}

1. (a) Badio, B.: Daly; J. W. Mol. Phamacol. 1994 45, 563. (b) Holladay. M. W.: Wasicak. J. T.: Lin. N.-H.: He. Y.: Ryther. K. B.: Bannon. A. W. Buckley, M. J.: Kim. D. J. B.: Decker. M. W: Anderson. D. J.: Campbell. J. E.: Kuntzweiler. T. A.: DonnellyRoberts. D. L.; Piattoni-Kaplan, M.; Briggs. C. A.; Williams, M: Americ. S. P. J. Med Chem 1998. 41. 407. (c) Moriva, K: Shibuta. K.: Hattori, Y.: Tsuboi. S.-i.: Shiokawa, K: Kagabu. S. Biosci. Biotech. Biochem. 1992. 56. 364.

2. (a) Franck. W. C.: Kim. Y. C.: Heck. R. F. J. Org. Chem. 1978. 13. 2947. (b) Mongin. F.: Trécourt. F.: Quéguiner. G. Tetrahedront Lett. 1999. 40, 5483. (c) Bremner. E.: Scluneider. R.: Fort. Y. Tetrahedron Lett. 2000. H. 2881.
3. Rama Rao. A. V: Yadav. J. S.: Valluri. M. Tetrahedron Lett. 1994. 35. 3613 .

4. For representative examples on the synthesis of halide-containing pridinedicarbosylic acids. see: (a) Lindenstruth. A. F.: Vanderwerf. C. A. J. An Chem. Soc. 1949. 71. 3020 (b) Cochran, J. C.: Little. W. F. J. Org Chem 1961. 26. 808. (c) Gadekar, S. M.; Fredereck, J. L.: Semb, J.; Vaughan, J. R.. Jr. J. Org. Chem. 1961, 26. 468.

5. For the ruthenium tetroxide oxidation of aromatic compounds. see: (a) Piatak. D. M.: Herbst. G.: Wicha. T.: Caspi. E. J. Org. Chent 1969. 34. 116. (b) Ayres. D. C.: Hossain. A. M. M. J Chent. Soc. Perkin Trans. I 1975, 707. (c) Carlsen, P. H. J.: Katsuki. T.: Martin, V. S.: Sharpless, K. B. J. Org. Chem. 1981. 46. 3936 . (d) Kasai. M.: Ziffer, H. J. Org. Chem. 1983. $48,2346$. (e) Nuinez. M. T.: Martín. V. S. J. Org. Chem. 1990. 55. 1928. (f) During manuscript preparationl. a very similar approach using $\mathrm{RuO}_{2}$ and $\mathrm{NaOCl}$ has been reported. see: Le Bas. M.-D.: Guéret. C.: Perrio, C.: Lasne. M.-C.; Barré, L. Smhesis 2001. 2495

6. Sugimoto. O.: Mori. M.: Tanji. K.-i. Tetrahedron Lett. 1999, 10. 7477 . 